\title{
READINESS AND COMPETENCE OF SENIOR HIGH SCHOOL ENGLISH TEACHERS TO IMPLEMENT CURRICULUM 2013
}

\author{
Wachyu Sundayana \\ Universitas Pendidikan Indonesia \\ swachyu@upi.edu, swachyu@yahoo.com \\ First draft received: 8 February 2015 \\ Final draft received: 30 June 2015
}

\begin{abstract}
The implementation of curriculum is considered as one of the most prominent phases after developing the 2013 primary and secondary curriculum in Indonesia, and this is greatly influenced especially by teachers' readiness and competence. This research was aimed to investigate teachers' readiness and competence to implement the 2013 Curriculum, particularly viewed from their comprehension about the syllabus of English and its articulation into lesson plans based on the principles of syllabus development as suggested in the curriculum. In addition, their ability and their self-efficacy in implementing the curriculum in classroom teaching and learning processes were also dealt with. Twelve senior high school teachers from different schools were assigned to complete a questionnaire about their readiness and competence to implement the 2013 curriculum and were observed in their teaching and learning process. Both quantitative and qualitative analyses were employed in the research. Results from quantitative analysis showed that teachers' readiness to implement the curriculum had low correlation to their competence. Qualitative analysis revealed that teachers had adequate readiness to implement the curriculum and adequate competence to develop lesson planning. For further studies, teachers' attitude, motivation, belief, and commitment as regards the implementation of the 2013 curriculum need to be further investigated.
\end{abstract}

Keywords: teachers' readiness and competence, lesson planning, ELT.

Curriculum in public schools is always changing along with what occurs in the society. As emphasized by Oliva and Gordon (2013), public schools, one of four major society's institutions, face contemporary problems, some of which threaten their existence. In order to survive, the schools have to respond and be able to solve the problems faced by the society by changing their curriculum. Therefore, it is apparent that curriculum change occurs in response to changes that take place in the society.

In context of the 2013 curriculum development in Indonesia, a country of almost 250 million people with diverse ethnic groups and numerous social-cultural backgrounds, curriculum change is indeed a complicated undertaking. As advocated by curriculum experts, many factors must be taken into account in changing the curriculum. In line with this, Schwab (1978) reiterates that there are "four commonplaces of curriculum" to be considered in designing and developing curriculum, namely teachers, learners, milieus, and subject matter.

The four common factors must be deeply thought in developing school curriculum by curriculum developers. At the implementation stage of the changed curriculum, teachers play crucial roles. Their knowledge of and ablity to implement curriculum components, i.e. goals and objectives, suggested contents, learning experiences, and assessments will help them implement the curriculum effectively. In other words, teachers' readiness to implement the school curriculum will be dependent upon their knowledge and ability to select, organize, and appropriately deliver the curriculum contents. In this connection, they have to know learners' characteristics, like their attitudes towards curriculum contents and their motivation to learn the contents of other subject matters will affect the successful implementation of the curriculum. The social-cultural aspects of the milieus surrounding the learners will also affect the curriculum development and implementation.

The characteristics of the 2013 Curriculum, as it is stated in the document, covers the following. As to the goals, the 2013 curriculum underlines the importance of attitudes and learners' needs to be covered. Competence standards in the previous curriculum, the 2006 curriculum, was based on the content standard. In addition to this, the standards did not cover the national goals of education, particularly the attitudes learning domain. In competence-based curriculum, this domain must be included. In addition, in the 2013 curriculum, competence standards are developed on the basis of needs. It is hoped that by considering learners' needs, the selected comptencies will be more relevant. With regard to the contents, selection and organization of the contents are based on the expected competencies. In the old curriculum, there was no connection between the two curriculum components. Viewed from the delivery system or presentation of contents, the 2013 curriculum suggests integrated and active learning processess that can help learners develop their skills including thinking skills, knowledge, and attitudes and behaviors as well. Regarding assessment, the curriculum adopts more authentic assessment which is adjusted to the nature of stated learning objectives or competencies. Therefore, the 2013 curriculum components are selected and 
organized more systematically than the old curriculum. In spite of the fact that the new curriculum has the positive sides in the context of competence-based curriculum development, it still has some problems in its implementation.

The 2013 Curriculum for primary and secondary schools in Indonesia has been through the stage of trial implementation in contributory schools assigned by the government. Many earlier problems actually occurred during the development of the curriculum. By tracing it according to the common structure of curriculum development, the problems came about during the stages of curriculum planning and deliberation, validation, and dissemination that in turn influenced its readiness for implementation.

As to planning, the frequently exposed and somewhat unbelievable issue was related to the evaluation of the implementation of the previous curriculum. For example, the rationale for developing Curriculum 2013 does not cover any data related to the evaluation of Curriculum 2006, i.e. the strengths and weaknesses of the curriculum as regards certain stages and components. The rationale is considerably based on academic assumptions and analysis on the preparation of educational institutions to help students facing the $21 \mathrm{st}$ Century with knowledge, competence, and attitude required in it. From the juridical point, the controversy is concerned with the contradiction between the spirit of developing Curriculum 2013 and the autonomy given to each provincial/regency education office to develop the curriculum as mandated by Law No. 20 Year 2003 on National Education System, especially Chapter X, Article 36, which particularly asserts that "the development of curriculum is based on National Standard and curriculum for all degrees, courses, and types of education is also developed based on diversification principles and adjusted to school and students' potentials." From the aspect of curriculum dissemination, the training program designed to provide comprehension and competence to teachers at target schools in order to be able to implement the curriculum is considered not effective yet. This condition can be indicated from insufficient intensive training (only 5 days) and unprepared instructors. In contrast, the demand for teachers' readiness to implement the curriculum is vital, apart from the aspect of comprehension and competence, and the demand to change their mindset is also challenging.

Those problems mentioned above certainly will influence teachers' readiness and competence to implement Curriculum 2013 as expected. Meanwhile, the reality shows that teachers at the practical level have insufficient pedagogical competence and skill, especially related to the implementation of Curriculum 2006. A study conducted by Sundayana (2013) suggests that teachers' comprehension on the development of teaching and learning instruments, i.e. syllabus and lesson plans, wasrelatively low (2.83 and 2.56 from scale of 5). The insufficiency of pedagogical knowledge and skills is indicated by the low quality of study results $(27.8 \%$ based on 2011 survey on PLPG participants, Alwasilah, 2012) and the ability to comprehend and develop teaching materials or professional competence and skills. Meanwhile, the national data on teachers' competence in both areas show the average of the result of Teacher's Competence Examination that is nationally still below 50 (34, Sundari, 2012, source: www.tempo.co) from the the national average of 44.55 from 243,619 participants (Puspitarini, 2012 source: www.kampus.okezone.com). Another study by Sundayana (2013) affirms that teachers' ability to develop the syllabus was not sufficient ( 2 in a scale of 5). This indicates that pedagogical knowledge of the teachers is still far from the expectation.

Teachers' comprehension on National Education Standard, especially their understanding on Content Standard and Process Standard of English subject, also presents an insufficient picture. Sundayana's study (2012) reveals that most (85\%) of Junior High School English teachers do not understand both standards. This condition occurs as they consider that understanding the standards as unnecessary and such misconception leads them to produce unsystematic instructional planning documents. This portrait is certainly in contrast to the requirement in prevailing regulation. The Laws No. 20, Year 2003 on National Education System, Article IX, Subsection 2, asserts that "National Education Standard functions as the basis of the development of school curriculum, educational agents, means and infrastructure, management and funding." Subsection (1) states that National Standards mentioned as the basis of school curriculum development are content standard, graduate's competence standard, process standard, and assessment standard. In the context of Curriculum 2013, those national standards have changed and need to be carefully comprehended by the teachers. Misconception on those standards will affect their perception and belief in implementing the curriculum. Some experts, such as Shulman (1986) and Clark and Peterson (1986), affirm that teachers' comprehension on the curriculum and other aspects in designing teaching and learning processes may influence their performance in implementing curriculum at school.

Other aspects to be considered by teachers in developing their instructional planning documents (syllabus and lesson plans) and implementing them are their comprehension about the characteristics of students, material mastery, their proficiency in using English as a tool for classroom interaction, and the methodology of teaching English as a foreign language and their ability to implement it.

The four aspects mentioned above, in the context of professional teachers' competence in Law No. 14 Year 2005, are closely linked to pedagogical and professional competencies. Both types of competence become one of the bases to actualize quality teaching and learning or quality learning outcomes as one of the purposes of the law. However, various studies and examinations on the achievement of both competencies, such as Teacher's Competence Examination, have not presented the expected results. 
Meanwhile, teacher readiness to implement Curriculum 2103 refers to some aspects of their comprehension, attitudes, and motivation in implementing the curriculum change. Weiner (2009) puts forward that individual and group readiness in an organization (school) in implementing the change (new curriculum) is influenced by many factors, including their perception, attitude, motivation, and knowledge of the program, and their ability to implement it. In line with this idea, Bandura (2012) states that one's belief and competence to do something (to implement the curriculum), known as self-efficacy, may determine the effectiveness of the implementation of a program (curriculum).

Studies related to teachers' readiness and knowledge in implementing the change, i.e. the implementation of the new curriculum (Curriculum 2013), are important to portray the aspects which need to be reinforced, particularly in line with teachers' knowledge of the curriculum and readiness to implement it, specifically among senior high school English teachers in West Java.

As described in the document of Public Examination of Curriculum 2013 (Hasan, 2013), the development of curriculum commonly progresses through some stages: a study on previous curriculum document, a study on future tendencies and challenges to deal with the 21 st century, a study on juridical aspect, especially on Law No. 20 year 2003 on National Education System, specifically in the chapter regarding the goal of national education and curriculum, a study on educational philosophy as the basic approach used in developing the curriculum, and a study on students' needs. In the development of curriculum, those studies become the foundation to guide curriculum developer to select and organize curriculum elements or components, starting from formulation of objectives, content, leaning experience, and selection of evaluation instruments.

Common procedures conducted to develop a curriculum (Print, 1993; Brown, 1995; Ornstein \& Hunkins, 2009) involve planning, validation, dissemination, implementation, and evaluation. From a series of those stages, the most critical and prominent stage for the success of the implementation of the curriculum is dissemination or socialization. Previous experiences suggest that socialization stage was often not well supervised, so that teachers were not able to handle the implementation carefully. A study conducted by Sundayana (2010) demonstrates that only a small number of junior high school teachers surveyed in West Java $(27.88 \%)$ comprehend the document of Curriculum 2006. Meanwhile, a study from Alwasilah (2012) also presents that low comprehension of teachers on the aspects related to pedagogical competence, including knowledge and mastery of prevailing curriculum (curricular knowledge) and the competence to implement it in teaching and learning processes makes insignificant contribution to the quality of learning $(27.8 \%$ based on 2011 survey of teachers in West Java). Therefore, socialization for the new curriculum (Curriculum 2013) can determine the success of its implementation.

In this context, Fullan (1982) emphasizes that educational change related to curriculum change will go through some stages. The first phase is initiation, mobilization, or adoption leading to the decision to accept the change or to adopt and adjust it as necessary. The second phase is the implementation that covers initial experiences and ideas in implementing the program. The third phase is the continuity of the implementation of the change referring to whether the change is integrated and united in the system (under development); or, on the contrary, it is decided to replace or repair the adoption of that change based on some inputs. In relation to curriculum change, from Curriculum 2006 to Curriculum 2013, the success of initiation stage in initial implementation of the curriculum at some pilot schools (senior high schools) can determine teachers' willingness to adopt the curriculum. In both stages, individual readiness reflected in comprehension and understanding on entire components of curriculum, starting from the formulation of competencies into the objectives of teaching and learning process to the selection of evaluation instrument, and self-efficacy to implement those components in teaching and learning process can determine the success of curriculum implementation.

The readiness to bring about a change for teachers at school as an organization becomes a crucial research topic. The readiness and willingness to adopt a change in education (curriculum change), as emphasized by Fullan (1982), will determine the success of the implementation of that change. In addition, Weiner (2009) upholds that "readiness for change refers to organizational members' shared resolve to implement a change (change commitment) shared belief in their collective capability to do so (change efficacy)" (p.1).

Teacher readiness to implement Curriculum 2013 involves many factors, including commitment, attitude, and motivation in dealing with the change, and definitely comprehension and understanding on the components of the curriculum. From those factors, three main factors are highly significant and should be examined comprehensively: teachers' belief and competence in implementing Curriculum 2013, teachers' motivation, and teachers' comprehension and understanding on the components of the curriculum. In this connection, a social psychology expert, Bandura (2012) asserts that if individuals' readiness (teachers at school) in an institution to implement a program change (curriculum) is excellent, the individuals tends to do more efforts to perform the implementation of that program, and to act more cooperatively and lead to effective implementation.

Many studies related to teachers' comprehension on curriculum conducted by Goh et al (2005) reveals that in dealing with curriculum change (syllabus), teachers' comprehension and understanding on the basic principles of curriculum are frequently inadequate, so that their competence to construct the components is also limited. Those studies clearly indicate that teachers' comprehension on the basic principles of a curriculum 
can influence their readiness and competence to describe the components of curriculum in the teaching and learning process, and also affect its implementation at school.

A study by Sundayana et al. (2013) on the comprehension of junior high school English teachers in West Java over Curriculum 2006 and their competence to implement it is not satisfactory. Their comprehension and competence in developing instructional planning documents (syllabus and lesson plans) are fairly low (2.83 and 2.56 from the scale of 5). This leads to low quality of students' learning outcomes (Alwasilah, 2012).

Data obtained from Teachers' Competence Examination also signify that teachers' competence related to the first two competencies, pedagogical and professional competencies, have not as reached the expected result. The national average of Teachers' Competence Examination result is still below 50. It means that the competence of certfied teachers is not sufficient compared to the expected professional and pedagogical competencies. A study by Sundayana (2012) on the comprehension and competence of junior high school English teachers taking part in PLPG (teachers' training program) to develop instructional planning documents shows that a large number of the participants $(85 \%)$ are considered incompetent (reach 2 from the scale of 5). Besides, their competence on basic teaching skills is also inadequate ( 2.5 from the scale of 5$)$.

Therefore, this research was focused on the readiness of senior high school English teachers in West Java to implement Curriculum 2013 and their competence to apply the curriculum in classroom activities. As put forward in the significance of the research on this topic, the data obtained are expected to be useful for UPI, especially for English Education Study Program in formulating appropriate training programs for teachers in implementing the curriculum.

\section{METHOD}

This research was conducted at secondary school level, specifically at senior high schools in West Java Province covering 6 cities and regencies. Samples were collected through purposive random method. Two schools from each city and regency were selected. This research also involved English teachers from selected schools.

This research combined quantitative and qualitative approaches. The former approach is implemented in the selection of survey design about the readiness of senior high school English teachers in implementing Curriculum 2013. The latter is reflected in the selection of multiple case study design at some pilot senior high schools for the implementation of the curriculum in correlation to teachers' competence to implement Curriculum 2013 in classroom activities. This research was focused on answering following questions: (1) To what extent are teachers ready to implement Curriculum 2013 as reflected from their comprehension, understanding, motivation, and self-efficacy to implement the curriculum?, (2) To what extent (level/method) are teachers able to apply their Lesson Plans in classroom activities?, and (3) Is there any correlation between teachers' readiness to implement the curriculum and their competence to implement curriculum 2013?

Research instruments utilized in this research

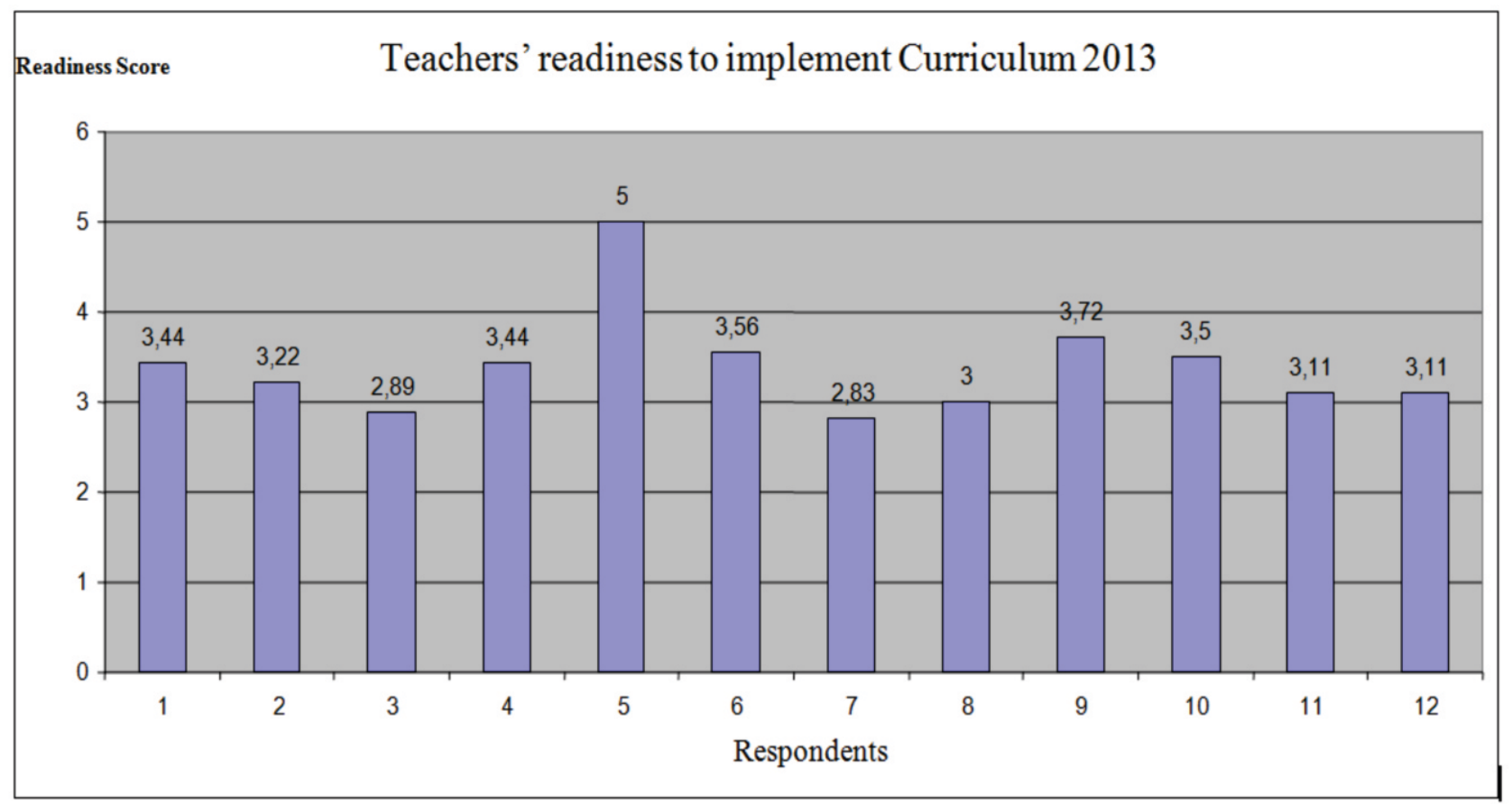

Figure1. Teachers' readiness to implement Curriculum 2013 
included: (1) questionnaire to collect the data about the readiness of senior high school English teachers in implementing Curriculum 2013 covering comprehension and understanding aspects related to the components of the 2013 curriculum; (2) and classroom observation to gain the picture of teachers' competence in implementing the curriculum. The two instruments were validated by the related experts and tried out in limited scope.

\section{RESULTS}

Teachers' readiness to implement Curriculum 2013

To obtain the data on teachers' readiness to implement Curriculum 2013, 12 respondents of teachers completed a questionnaire consisting of 18 perceptual questions. From the data collected, the average score for teachers' perception of their comprehension in developing lesson plans to deal with the implementation of Curriculum 2013 is 3.40 (from maximum score of 5.00). This score suggests that in general, teachers have sufficient knowledge and readiness to implement Curriculum 2013. The item analysis on each question in the questionnaire completed by respondent teachers suggests that the average answer for each question item is between 3.17 and 3.67 (in scale of 5) and it implies that their comprehension and readiness are adequate. The data of teachers' readiness to implement Curriculum 2013 can be observed in Figure 1.

Teachers' competence in developing the components of syllabus into lesson plans

To collect the data on teachers' competence to develop syllabus components into lesson plans, the 12 respondent teachers also completed a questionnaire consisting of 18 perceptual questions. The questions are related to teachers' competence to comprehend the principles and stages of lesson plan development for English subject, comprehension about graduate's competence standard (SKL), and formulation of indicator, formulation of objectives and stages of scientific teaching and learning process, comprehension and implementation of assessment for the three aspects (attitude, knowledge, and skill), classroom management and question strategy, and understanding on lesson plan adjustment method for English subject and classroom activities. Based on the data collected, the average perception of teachers on teachers' competence in developing syllabus components into lesson plans is 3.40 (from maximum score of 5.00). The result suggests that teachers generally have adequate competence to develop syllabus components into lesson plans. The item analysis on each question in the questionnaire completed by respondent teachers suggests that the average answer for each question is between 3.17 and 3.67 (scale of 5) and it also asserts that teachers' competence to develop syllabus components into lesson plans are highly adequate as portrayed in Figure 2.

Teachers' implementation of Curriculum 2013 at school To collect the data of the implementation of Curriculum 2013 by teachers in their teaching learning process at school, the researchers observed classroom activities of 12 respondent teachers. The observation was conducted either directly or indirectly by means of video recording instrument. The researchers took some notes and filled in observation forms based on a rubric specifically designed for the classroom observation consisting of several criteria and points of observation.

Classroom observation was focused on some aspects of teachers' teaching and learning process, comprising (1) pre-activity, (2) main activity, and (3)

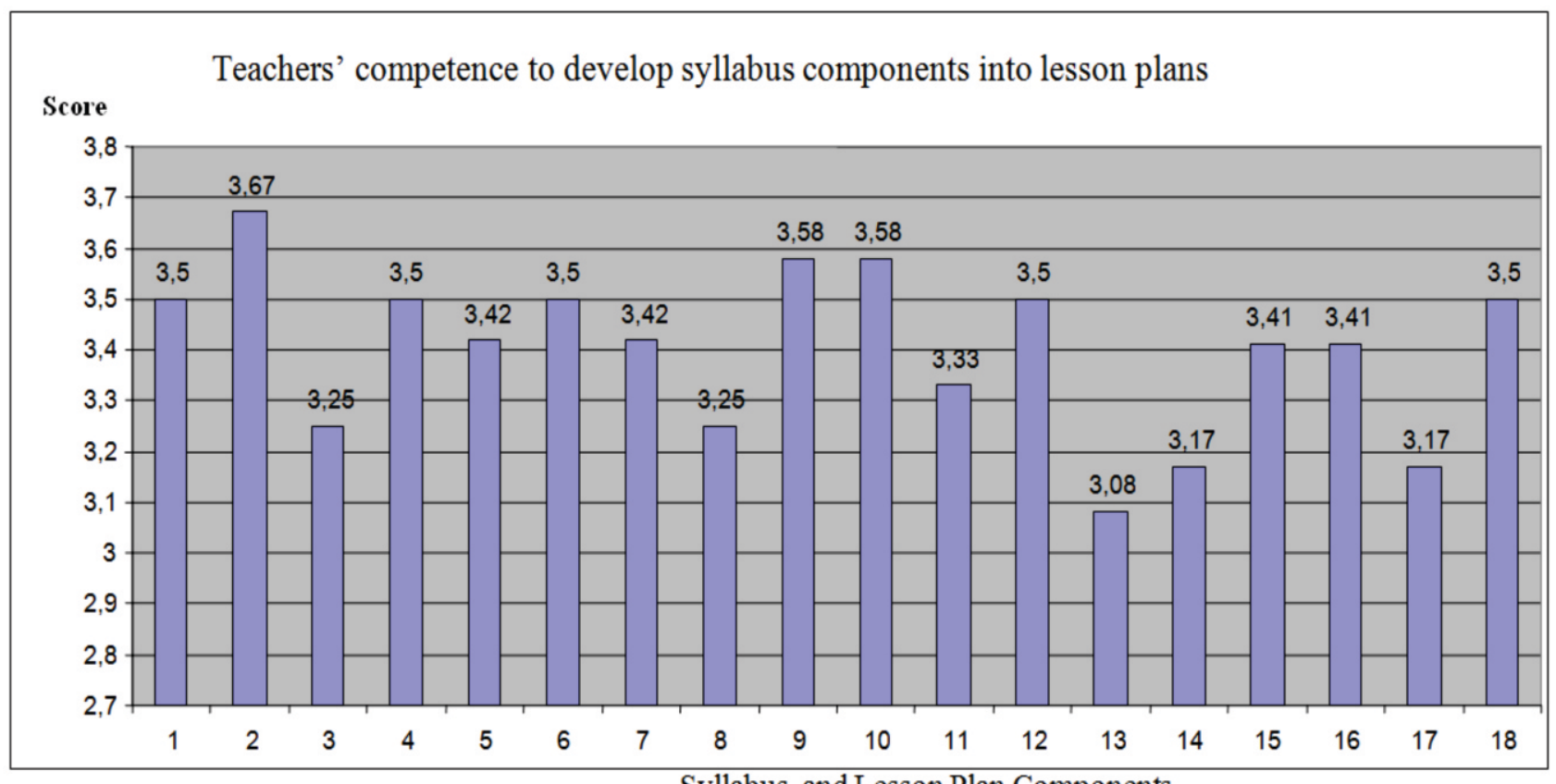

Syllabus and Lesson Plan Components

Figure 2. Teachers' competence to develop syllabus components into lesson plans 
post-activity. From data collected through classroom observation, there are several points resulted. (1) The average score of pre activity performance is 4.00 from maximum score of 5.00. It suggests that teachers generally achieved good points in Pre Activity aspect. (2) The average score of opening performance is 3.33. It indicates that most teachers have relatively adequate score in implementing their lesson plans during the

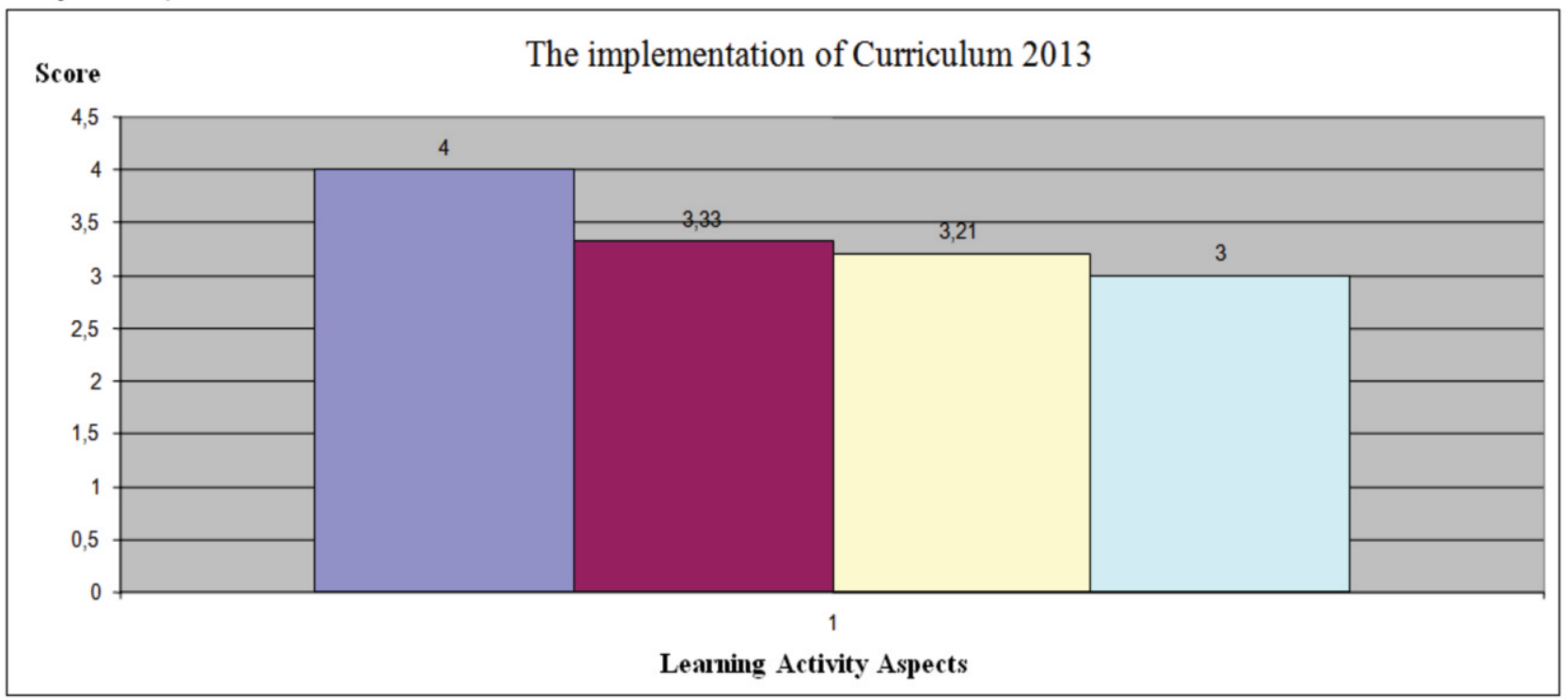

Figure 3. The implementation of Curriculum 2013 by teachers at school

opening. (3) The average score of main activity performance (including the mastery of materials, teaching and learning approaches/ strategies, the use of appropriate media, activities motivating and sustaining students' discipline, and assessment of study result) is 3.21 from maximum score of 5.00. This score denotes that teachers are moderately competent in implementing their lesson plans into the main activity. (4) The average score of post-activity performance is 3.00 from maximum score of 5.00. It shows that teachers in general are fairly proficient in implementing their lesson plans into the closing.

It can be implied from the data presentation of lesson plan implementation in classroom activity based on Curriculum 2013 above that teachers at school have been able to implement Curriculum 2013 fairly well and even better. It can also be concluded that most teachers are relatively-well-prepared to implement Curriculum 2013 in classroom activity as indicated by the conformity of lesson plan and teachers' actual performance in the classroom, which is presented in Figure 3.

The correlation between teachers' readiness to implement the curriculum and their competence to implement Curriculum 2013

The collection of data about teachers' readiness to implement Curriculum 2013 portrays that most teachers are adequately ready (3.40 from maximum score of 5.00). Besides, the data collected from the observation on the average competence of teachers to implement Curriculum 2013 denotes that teachers generally have sufficient competence (3.44 from maximum score of $5.00)$. It can also be concluded that teachers in general only have moderate readiness, but have not reached higher degree, either in their readiness to implement curriculum 2013 or their competence to implement Curriculum 2013 in the classroom or at school.

In line with the correlation between both aspects (teachers' readiness to implement curriculum 2013, and teachers' competence to implement Curriculum 2013 at school), the data are presented in Table 1, in which line $X$ refers to teachers' readiness and line $Y$ refers to teachers' competence in implementing Curriculum 2013.

From statistical calculation on the data presented in Table 1, Pearson correlation coefficient score has emerged indicating the correlation between teacher's readiness and competence to implement Curriculum 2013 at school with $\boldsymbol{r}=\mathbf{0 . 4 2 8 4}$. The correlation coefficient points out that technically, both variables have positive correlation, but their relation is inadequate. Thus, it can be concluded that teachers' readiness to implement Curriculum 2013 has low correlation to their competence

Table 1. The average score of teachers' readiness and competence to implement Curriculum 2013 at school

\begin{tabular}{lllllllllllll}
\hline Readiness & 3.44 & 3.22 & 2.89 & 3.44 & 5.00 & 3.56 & 2.83 & 3.00 & 3.72 & 3.50 & 3.11 & 3.11 \\
\hline Competence & 3.50 & 3.20 & 3.20 & 3.60 & 3.60 & 3.60 & 3.55 & 3.40 & 3.40 & 3.45 & 3.50 & 3.45 \\
\hline
\end{tabular}


to implement the curriculum at school.

\section{DISCUSSION}

From the data of comprehension of junior high school English teachers in West Java, it can be perceived that they adequately comprehend the stages of the development of teaching and learning instruments reflected from their perception. The documents of teaching learning instruments that they develop certainly need to be examined. However, this research does not cover the analysis of lesson plan documents considering the scope of the research focused on the comprehension aspect. Data presented in Figure 1 underlines that teachers' comprehension on the development of lesson plan is fairly adequate. The average score of teachers' perception on teaches' comprehension about the development of lesson plan in relation to the implementation of Curriculum 2013 is 3.40 (from maximum score of 5.00). This condition is certainly encouraging, it is assumed that teachers' comprehension on the development of teaching and learning instruments are satisfactory. Hence, it can be implied that training provided thus far for guiding teachers in developing their lesson plans have reinforced their comprehension.

Meanwhile, senior high school English teachers in West Java can be considered to have moderate competence in implementing their lesson plan into teaching and learning activities, as depicted in Figure 3. This condition can be indicated from the average score of their competence in applying teaching and learning process as observed and categorized as adequate. Further, it is also reflected in teachers' average score in pre activity and opening aspects that gains 3.33 points. Similarly, the average score of the main activity performance (including the mastery of materials, teaching and learning approaches/ strategies, the use of appropriate media, activities motivating and sustaining students' discipline, and assessment of study result) is 3.21 from maximum score of 5.00 .

This portrait indicate that teachers' competence to implement lesson plan in the class is relatively sufficient in line with their comprehension to develop teaching and learning instruments. This condition infers that training programs provided for teachers at schools involved in this research are reasonably successful.

Nevertheless, from the aspect of correlation between comprehension and competence to implement lesson plan in classroom activity, the data indicate insufficiently positive correlation. This may lead to many interpretations, such as the possibility of other nonobservable aspects of teaching and learning process, like classroom language, or teachers' guidance for students that may be imprecise. Therefore, further analysis on the aspects of teacher-student classroom interaction through classroom discourse analysis need to be covered in further study. It is unfortunate that this research does not cover that area.

\section{CONCLUSION AND SUGGESTION}

This research was focused on three main problems. The first is the comprehension of junior high school English teachers in West Java about the development of lesson plans in the context of Curriculum 2013. The next one is teachers' competence to perform teaching and learning process appropriate to the principles of teaching and learning in Curriculum 2013. The third is the correlation between teachers' comprehension about lesson plans and their competence to apply them in the teaching and learning process.

Related to teachers' competence to develop a lesson plan, the data shows that the average score of 12 respondent teachers' perception on teachers competence to develop syllabus components into lesson plan is 3.40 (from maximum score of 5.00). This condition shows that generally, teachers are relatively competent to develop syllabus components into lesson plans. Item analysis for each question in the questionnaire completed by respondent teachers suggests that the average score for each answer is between 3.17 and 3.67 (in scale of 5). The score denotes that most teachers' proficiency to develop syllabus components into lesson plan is almost excellent as depicted in Figure 2.

In the aspect of teachers' competence to implement a lesson plan in the teaching and learning process, the data from classroom observation reveal some aspects of teachers' teaching and learning activities including: (1) pre-activity, (2) main activity, and (3) post-activity.

The data obtained from the classroom observation further signify that teachers observed have adequate competence. This view is supported by the average score of teachers in performing the opening that acquires 3.33. The main activity that includes the mastery of materials, teaching and learning approaches/ strategies, the use of appropriate media, activities motivating and sustaining students' discipline, and assessment of study result scores 3.21 from maximum score of 5.00. Likewise, the closing performed by the teachers is also reasonably satisfactory.

From the data above, teachers' comprehension and competence in developing and implementing lesson plans can be considered adequate. This implies that their readiness to implement curriculum 2013 is rather sufficient. However, the correlation between both aspects is not positive. This may suggest that teachers' readiness and competence to implement Curriculum 2013 in teaching and learning process do not indicate low correlation.

Therefore, the readiness of senior high school English teachers in West Java viewed from their comprehension on the development of teaching and learning instruments (lesson plans) and competence to organize those does not necessarily reflect their teaching competence. As emphasized by many experts (DarlingHammond, Bransford, and Le Page 2005), teachers' comprehension related to their knowledge about teaching and learning and material mastery is considered inadequate if their comprehension and competence to implement teaching and learning methods are not line with students' characteristics. Corresponding to that 
notion, a study by Goh et al. (2005) indicates that to deal with curriculum change (syllabus), teachers' comprehension and understanding on the basic principles of curriculum are frequently inadequate, so that their competence to implement them in the teaching and learning process is also limited.

To obtain a comprehensive and detailed picture, it is suggested that studies on the implementation of Curriculum 2013 have to be conducted, for example in dealing with the preparation of school management and school organization climate in implementing the curriculum. Moreover, studies on teachers' attitude, motivation, belief, and commitment to implement the new curriculum have to utilize broader and more profound analyses.

\section{REFERENCES}

Alwasilah, A. C. (2012). Teachers as researchers; Is it possible in Indonesia? In The Jakarta Post, Saturday, September 1, 2012.

Brown, J.D. (1995). The elements of language curriculum; A systematic approach to program development. Boston, Msss: Heinle\&Heinle Publishers.

Bandura, A. (2012). On the functional properties of perceived self-efficacy revisited. Journal of management.38(9), pp. 9-39.

Clark, C. M., \& Peterson, P. L. (1986). Teachers' thought processes. In M. C. Wittrock (Ed.), Handbook of research on teaching (3rd ed., pp. 255-296). New York: Macmillan.

Darling-Hammond, L., Bransford, J. \& Le Page, P. (2005). Introduction. In Darling Hammond, L. \& Bransford, J. (Eds.). Preparing teachers for a changing world. San Fransisco: Jossey-Bass Publisher pp. 1-39.

Fullan, M. (1982). The meaning of educational change. Toronto: OISE Press

Goh, C.M., Zhang, L.J., Ng, C.H., \& Koh, G. H. (2005). Knowledge, beliefs and syllabus implementation; A study of English language teachers in Singapore. Singapore: Graduate Programmes and Research Office, National Institute of Education, Nanyang Technological University. Retrieved March 3, 2014 from: https://repository.nie.edu.sg/bitstream/10497/3696 /3/EdRF_Goh07.pdf

Hasan, H.S. (2013). Bahan sosialisasi kurikulum 2013.
Presented at Curriculum Development Study Program, School of Postgraduate Studies, UPI.

Law of the Republic of Indonesia, No. 14, Year 2015 on teachers and lecturers.

Law of the Republic of Indonesia, No. 20, Year 2003 on national education system.

Oliva, P.F. \& Gordon, W . (2013). Developing the currilum; Eighth edition. Upper Saddle River, NJ: Pearson.

Ornstein, A.C. \& Hunkins, F.P.(2009). Curriculum; foundations, principles, and isuues, 5th Ed. Boston, M.A.: Pearson.

Print, M. (1993). Curriculum development and design $2^{\text {nd }} E d$. Sydney: Allen \& Unwin.

Puspitarini, M. (2012). UKG, kemampuan guru bahasa minim. Retrieved February 12, 2013 from: http://kampus.okezone.com/read/2012/08/03/373/ 672954/ukg-kemampuan-bahasa-guru-minim.

Schwab, J. J. (1978). Science, curriculum, and liberal education: Essays. Chicago: University of Chicago Press.

Shulman, L.S. (1986). "Paradigms and research programs in the study of teaching: A contemporary perspective, in Handbook of research in education. New York: Macmillan.

Sundari. (2012). Kemampuan guru bahasa Inggris SMP memprihatinkan. Retrieved February 12, 2013 from:

http://www.tempo.co/read/news/2012/08/05/0794 21508/Kemampuan-Guru-Bahasa-Inggris-SMPMemprihatinkan.

Sundayana, W. (2010). "Persepsi guru bahasa Inggris terhadap pengembangan kurikulum tingkat satuan pendidikan". Jurnal Himpunan Pengembang Kurikulum Indonesia, 3, pp. 25-30.

Sundayana, W. (2012). "Kemampuan guru bahasa Inggris SMP dalam pengembangan kurikulum tingkat satuan pendidikan". Unpublished research report, Universitas Pendidikan Indonesia.

Sundayana, W. (2013). Pengetahuan dan kemampuan guru bahasa Inggris SMP dalam pengembangan perangkat pembelajaran. Unpublished research report, Universitas Pendidikan Indonesia.

Weiner, B.J. (2009). A theory of organizational readiness for change. Implementation Science, 4(67). doi: 10.1186/1748-5908-4-67. Retrieved October 19, 2013 from: http://www.implementationscience.com/content/4/1 $/ 67$ 